\title{
Phytoplankton assemblages in a reservoir cascade of a large tropical - subtropical river (SE, Brazil)
}

\author{
Nogueira, MG.*, Ferrareze, M., Moreira, ML. and Gouvêa, RM. \\ Departamento de Zoologia, Instituto de Biociências, Universidade Estadual Paulista - UNESP, \\ Campus de Rubião Júnior, CP 510, CEP 18610-000, Botucatu, SP, Brazil \\ *e-mail: nogueira@ibb.unesp.br
}

Received January 08, 2010 - Accepted June 05, 2010 - Distributed October 31, 2010

(With 13 figures)

\begin{abstract}
The phytoplankton assemblages from eight reservoirs of the Paranapanema River were studied during two consecutive years. Chlorophyceae and Bacillaryophyceae dominated in richness. The observed high number of taxa, 234, reflects the extensive sampling programme and evidences the necessity of considering the whole hydrograph basin to assess the biodiversity status of inland water ecosystems. The dams had a negative effect on phytoplankton richness, with higher number of taxa associate to riverine (non-regulated) stretches. The tributary rivers also exhibited high species richness, showing the importance of considering the lateral dimension, in addition to the longitudinal one, for aquatic biota inventories in large river basins/reservoirs. Richness and diversity were also positively influenced by the connectivity with lateral wetlands (macrophyte-dominated lakes) due to the periphyton influence. The phytoplankton abundance/ biomass was not influenced by higher water retention time. Higher values occurred in the middle basin stretches (riverpassage reservoirs) due to the increase in the trophic conditions. There was a positive correlation with phosphorus. Poorer light conditions in the cascade do not limit the phytoplankton biomass, with assemblages dominated by species tolerant to turbulent conditions and high mineral turbidity. Bacillariophyceae and Cryptophyceae dominated numerically. The first group (unicellular forms) was prominent in the large and oligotrophic upstream reservoirs. The second was highly abundant in the river-passage (low retention time), and more eutrophic, reservoirs. Cyanophyceae growth is probably controlled by advection processes (wash-out effect). The zooplankton does not control the phytoplankton biomass and the diversity of both groups is positively associated in the cascade. The structure of the phytoplankton assemblages showed to be a good indicator of the operationally distinct reservoirs of the Paranapanema cascade and also reflected the changes in the trophic conditions along the basin.
\end{abstract}

Keywords: Paranapanema River, Chlorophyceae, Bacillaryophyceae, Cryptophyceae, reservoir limnology.

\section{Assembleias fitoplanctônicas de reservatórios em cascata de um rio tropical - subtropical de grande porte (SE, Brasil)}

\section{Resumo}

As assembleias fitoplanctônicas de oito reservatórios do rio Paranapanema foram estudadas durante dois anos consecutivos. Chlorophyceae e Bacillaryophyceae foram os grupos dominantes em riqueza. O elevado número de táxons observado, 234, reflete o extensivo programa de amostragem e evidencia a necessidade de se considerar a bacia hidrográfica como um todo em programas de avaliação da biodiversidade de ecossistemas aquáticos interiores. As barragens tiveram um efeito negativo sobre a riqueza do fitoplâncton, sendo o maior número de táxons associado aos trechos fluviais (não regulados). Os rios tributários também exibiram um elevado número de espécies, mostrando a importância de se considerar a dimensão lateral, além do gradiente longitudinal, para os inventários da biota aquática em reservatórios e bacias hidrográficas de grande porte. A riqueza e a diversidade também foram positivamente influenciadas pela conectividade com áreas laterais inundáveis - várzeas dominadas pela presença de macrófitas aquáticas, devido à contribuição do perifíton. A abundância e biomassa do fitoplâncton não foram influenciadas pelo tempo de retenção da água nos reservatórios. Valores mais elevados foram observados no médio Paranapanema (reservatórios fio d'água) devido ao aumento nas condições de trofia. Houve uma correlação positiva com a concentração de fósforo. Condições de menor transparência não limitaram a biomassa fitoplanctônica, sendo as assembleias dominadas por espécies tolerantes a condições de elevada turbulência e turbidez mineral. Bacillariophyceae e Cryptophyceae foram as algas numericamente dominantes. O primeiro grupo (formas unicelulares) predominou nos grandes reservatórios oligotróficos do alto Paranapanema. O segundo grupo foi muito abundante em reservatórios do tipo fio d'água (baixo tempo de retenção) e também mais eutróficos. Provavelmente o crescimento das Cyanophyceae é controlado por processos de transporte advectivo. O zooplâncton não exerce um controle sobre a biomassa fitoplanctônica e a diversidade de ambos os grupos esteve positivamente associada na cascata. A estrutura das assembleias fitoplanctônicas pode ser considerada um bom indicador das distintas condições de operação dos reservatórios em cascata do rio Paranapanema e também reflete as mudanças nas condições oligotróficas ao longo da bacia.

Palavras-chave: Rio Paranapanema, Chlorophyceae, Bacillaryophyceae, Cryptophyceae, limnologia de reservatórios. 


\section{Introduction}

A major human induced impact on Brazilian rivers is dam construction for power generation. The hydropower potential of the country is one of the largest in the world and presently $97 \%$ of the produced electricity (ca. $67.000 \mathrm{MW}$ ) is provided by hydroelectric plants (Agostinho et al., 2007). An integrated and complex generation system supplies relatively clean and renewable energy but causes deep changes in the ecological structure and functioning of important fluvial basins (Tundisi et al., 1993; Tundisi and Matsumura-Tundisi, 2003).

Large reservoirs are distributed all over the country, but their number is particularly high in the Southeast region, where they have been intensively constructed since the 1950 's. Despite the primary use of reservoir power generation, other uses have rapidly increased such as irrigation, leisure, drinking water supply, sewage assimilation, fishery and aquaculture. Conflicts among the distinct activities are expected due to the insufficient planning capability and the present scenario of climatic incertitude.

The accumulated limnological knowledge on reservoirs has provided a growing understanding of these systems as unique class of lakes, but it is still incomplete (Kennedy et al., 2003). Additionally, besides the traditional research approaches, new practical questions have been posed to aquatic ecologists by reservoir managers and engineers (Tundisi and Matsumura-Tundisi, 2003). In case of reservoir cascades, just a few efforts have been undertaken to determine how their functioning affect the river ecological structure and functioning (e.g. Barbosa et al., 1999; Jorcin and Nogueira, 2005a, b; Naliato et al., 2009). Presently new reservoir cascades are under construction in large Brazilian rivers (mainly in the south and north regions) in order to support the electricity demand of an increasing economical and demographic trend.

A pioneer survey of a series of connected reservoirs in Brazil, with a limnological integrated river-basin approach, was carried out in the Tietê River (State of São Paulo) by Tundisi et al. (1991). However, detailed investigations of the influence of Brazilian reservoir cascades on the aquatic biota are still scarce. Studies along 8 reservoirs in the Tietê River (Padisák et al., 2000) and 5 reservoirs in the Iguaçu River (Paraná State) (Silva et al., 2005) showed that phytoplankton is highly affected by hydrodynamic changes. Another regional (Paraná-La Plata basin) study on phytoplankton of a cascade system was carried out in 3 consecutive reservoirs of the Negro River (Uruguay) (Bonilla, 1997).

Structural changes of the phytoplankton assemblages along the previously mentioned cascades - longitudinal trends, nutrient enrichment and water retention time, seemed to vary according to the intrinsic differences of the river systems. Nevertheless, comparisons are methodologically limited due to the low sampling frequency - only once (Bonilla, 1997; Padisák et al., 2000) or twice (Silva et al., 2005), and only a single sampling station just above dam. It is already known that the phytoplankton distribution in reservoirs of the Paraná-La Plata basin are highly affected by the usually complex spatial structure and conspicuous seasonal changes (mainly dry-wet periods) (Henry et al., 1998; Nogueira, 2000; De León and Chalar, 2003; MatsumuraTundisi and Tundisi, 2005; Soares et al., 2008).

The present study analyses the phytoplankton variability (inter and intra-reservoir) along a cascade of eight reservoirs constructed for hydroelectric production in the Paranapanema River (São Paulo State). Changes in composition, abundance and diversity were followed during two consecutive years. It is hypothesised that the main driving forces determining the phytoplankton assemblages structure is the hydrodynamics (mainly water retention time) and the trophic conditions. An additional hypothesis is that the river is, naturally, large enough to support a high phytoplankton diversity, possibly higher than in the reservoirs. Besides phytoplankton, the zooplankton (Nogueira et al., 2008) and benthic macroinvertebrates (Jorcin and Nogueira, 2008) were simultaneously sampled during the study, and the distributional patterns of these distinct biological groups are compared.

Previous studies on phytoplankton assemblages of the Paranapanema basin (taxonomy, organizational structure and productivity) were carried out by Henry (1990, 1993), Henry et al. (1998), Nogueira (2000), Bittencourt-Oliveira (2002), Ferrareze and Nogueira (2006), Henry et al. (2006a, b) and Bicudo et al. (2006).

\section{Material and Methods}

\subsection{Study area}

The hydrographic basin of the Paranapanema River $\left(100.800 \mathrm{~km}^{2}\right)$ is located between the coordinates $22^{\circ}-26^{\circ} \mathrm{S}$ and $47^{\circ}-54^{\circ} \mathrm{W}$, on the tropical - subtropical boundary (Southeast/South Brazil). The river main course is east-west oriented and has an extension of $929 \mathrm{~km}$ and a declivity of $570 \mathrm{~m}$ (Figure 1). Since de 1950's 11 reservoirs have been constructed in the river main course for hydroelectric generation. For this study, the eight largest reservoirs were selected.

Some limnological characteristics of the studied cascade are presented by Jorcin and Nogueira (2005a, b; 2008) and Nogueira et al. (2008). The large reservoirs (lacustrine zones of Jurumirim, Chavantes and Capivara), remain stratified from late spring and summer and there is a complete mixing period during the winter, or even in late autumn. The other reservoirs exhibit frequent mixing conditions or minor vertical gradients throughout the year.

In the region there is a marked concentration of rains in summer and dry weather predominates in winter. The annual precipitation varied between $969 \mathrm{~mm}$ (Capivara dam) to $1,600 \mathrm{~mm}$ (Jurumirim dam) during the studied period.

\subsection{Samplings and laboratory analyses}

Eight sampling campaigns were carried out over two consecutive years: during summer (January 2000 and 2001), autumn (April 2000 and 2001), winter (July 2000 

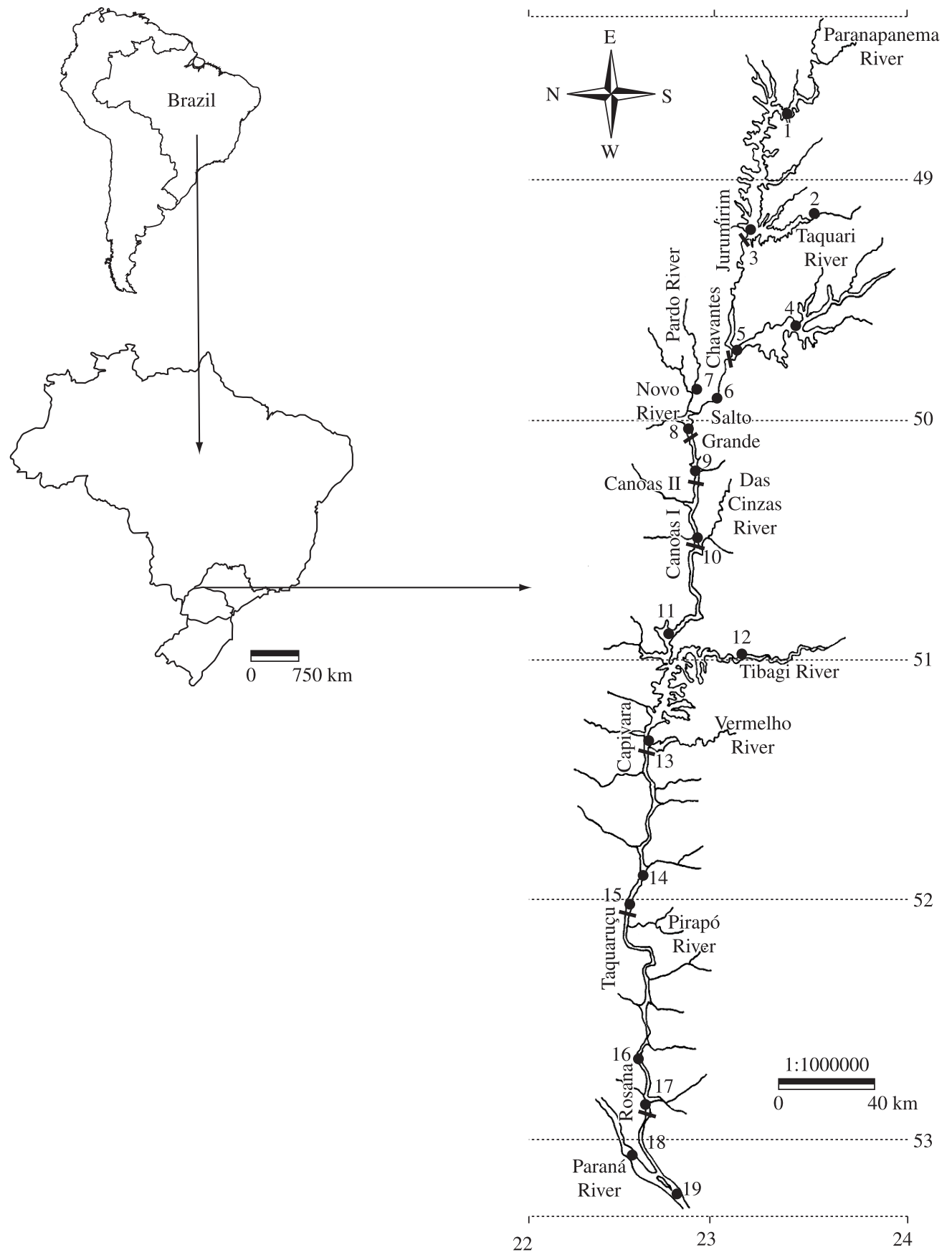

Figure 1. The Paranapanema River basin and location of the sampling stations.

and 2001) and spring (October 2000 and 2001). Data were collected at nineteen sampling stations (Figure 1; Table 1) distributed along $700 \mathrm{~km}$, approximately. The sampling design included the upstream (river-reservoir transition) and dam (lacustrine) zones of six reservoirs (Jurumirim, Chavantes, Salto Grande, Capivara, Taquaruçu and Rosana), only the dam zone of two reservoirs (Canoas I and II) and the mouth of the three main tributary rivers of the watershed (Taquari, Pardo and Tibagi).
The main limnological characteristics of each point are shown in Table 2.

In each sampling station an integrated sample was collected (entire water column) through vertical net hauls (20 $\mu \mathrm{m}$ of mesh size) and immediately preserved in $4 \%$ formalin. The net samples were observed in an optical microscope (maximum magnification of 1000×) for preliminary taxonomical identifications and computed for richness. 
Table 1. Denomination of the sampling stations and their position in the Paranapanema River reservoir cascade.

\begin{tabular}{ccl}
\hline Station & Abbreviation & \multicolumn{1}{c}{ Location } \\
\hline 1 & JU & Upstream of Jurumirim Reservoir \\
2 & TaqR & Taquari River \\
3 & JD & Dam zone of Jurumirim Reservoir \\
4 & ChU & Upstream of Chavantes Reservoir \\
5 & ChD & Dam zone of Chavantes Reservoir \\
6 & SGU & Upstream of Salto Grande \\
& & Reservoir \\
7 & ParR & Pardo River \\
8 & SGD & Dam zone of Salto Grande \\
& & Reservoir \\
9 & CIID & Dam zone of Canoas II Reservoir \\
10 & CID & Dam zone of Canoas I Reservoir \\
11 & CAU & Upstream of Capivara Reservoir \\
12 & TibR & Tibagi River \\
13 & CAD & Dam zone of Capivara Reservoir \\
14 & TU & Upstream of Taquaruçu Reservoir \\
15 & TD & Dam zone of Taquaruçu Reservoir \\
16 & RU & Upstream of Rosana Reservoir \\
17 & RD & Dam zone of Rosana Reservoir \\
18 & PMU & Upstream of Paranapanema River \\
& & mouth \\
19 & PMD & Downstream of Paranapanema \\
& & River mouth \\
\hline & & \\
& & \\
& &
\end{tabular}

For the quantitative analysis of the phytoplankton, four unfiltered samples were collected (van Dorn bottle) at each sampling station at the subsurface (ca. $0.2 \mathrm{~m}$ ), middle and immediately below the euphotic zone and near to the bottom (ca. $1 \mathrm{~m}$ above the sediment). The samples were fixed and preserved with Lugol solution. After sedimentation, the organisms (cell, colony, and filament) were counted using inverted microscopy (sensu Utermöhl) at a magnification of $250 \times$. At least 120 optical fields distributed in parallel transects were examined, and at least 150 organisms were counted per sample. In the results section quantitative data are expressed as mean values for the water column.

Chlorophyll- $a$ (total) concentration was determined through filtration (Millipore AP40 membranes) of $800 \mathrm{~mL}$ of water from each sampling depth (see above). For pigments extraction, cold acetone (90\%) was used with manual maceration (Talling and Driver, 1963; Golterman et al., 1978).

Phytoplankton diversity was estimated using the Shannon-Wiener Index ( $\log _{2}$; Krebs, 1989).

Unvaried tests (t-student; Statsoft, 2006) were used for comparisons of the phytoplankton distribution - reservoirs and tributaries, distinct reservoir compartments (upstream and dam zones) and sampling periods (seasons). Data normality was previously checked by the Tukey test (Statsoft, 2006). Sampling stations were compared on the basis of the phytoplankton structure (class abundance) through a

Table 2. Physical and chemical characteristics of the sampling stations (mean values among depths and sampling periods).

\begin{tabular}{|c|c|c|c|c|c|c|c|c|c|c|}
\hline & $\begin{array}{c}\text { TN } \\
\left(\mu \mathrm{g} \cdot \mathbf{L}^{-1}\right)\end{array}$ & $\begin{array}{c}\text { TP } \\
\left(\mu \mathbf{g} \cdot \mathbf{L}^{-1}\right)\end{array}$ & $\begin{array}{c}\text { Transp. } \\
(\mathbf{m})\end{array}$ & $\begin{array}{c}\text { EC } \\
\left(\mu \mathrm{S} . \mathrm{cm}^{-1}\right)\end{array}$ & $\begin{array}{c}\text { DO } \\
\left(\mathrm{mg} \cdot \mathrm{L}^{-1}\right)\end{array}$ & pH & $\begin{array}{l}\text { Turb. } \\
\text { (FTU) }\end{array}$ & $\begin{array}{c}\text { TSS } \\
\left(\mathrm{mg.L}^{-1}\right)\end{array}$ & $\begin{array}{c}\text { TOC } \\
(\mathbf{p p m})\end{array}$ & $\begin{array}{c}\text { RT } \\
\text { (days) }\end{array}$ \\
\hline $\mathrm{JU}$ & 513 & 58 & 0.9 & 71 & 8.7 & 6.4 & 11.5 & 13.8 & 8.4 & \multirow{3}{*}{528} \\
\hline TaqR & 493 & 49 & 1.0 & 90 & 7.1 & 6.5 & 6.2 & 10.5 & 11.0 & \\
\hline JD & 398 & 24 & 3.6 & 74 & 6.5 & 6.7 & 1.8 & 1.9 & 7.2 & \\
\hline Chu & 398 & 29 & 2.1 & 74 & 6.5 & 6.6 & 2.2 & 2.7 & 7.3 & \multirow{2}{*}{401} \\
\hline $\mathrm{ChD}$ & 410 & 24 & 4.5 & 73 & 6.2 & 6.6 & 2.0 & 2.7 & 7.0 & \\
\hline SGU & 422 & 27 & 3.3 & 64 & 8.4 & 6.4 & 2.1 & 1.7 & 7.5 & \multirow{3}{*}{1.4} \\
\hline ParR & 432 & 64 & 1.0 & 77 & 8.6 & 6.6 & 7.6 & 18.4 & 10.0 & \\
\hline SGD & 417 & 35 & 2.3 & 64 & 8.4 & 6.7 & 3.4 & 7.3 & 8.4 & \\
\hline CIID & 408 & 34 & 1.8 & 68 & 7.8 & 6.6 & 3.0 & 5.2 & 8.4 & 4.7 \\
\hline CID & 337 & 31 & 2.4 & 68 & 7.7 & 6.6 & 2.0 & 2.1 & 7.1 & 6.4 \\
\hline CAU & 435 & 36 & 2.0 & 83 & 6.5 & 6.8 & 3.1 & 3.6 & 9.4 & \multirow{3}{*}{137} \\
\hline TibR & 477 & 55 & 0.9 & 64 & 6.5 & 5.2 & 7.2 & 7.6 & 7.3 & \\
\hline CAD & 416 & 30 & 2.0 & 76 & 7.7 & 7.0 & 3.5 & 2.7 & 8.4 & \\
\hline $\mathrm{TU}$ & 404 & 30 & 2.3 & 72 & 7.8 & 6.7 & 2.8 & 1.2 & 8.1 & \multirow{2}{*}{8.0} \\
\hline TD & 401 & 24 & 2.5 & 74 & 8.2 & 6.9 & 2.5 & 1.4 & 8.1 & \\
\hline RU & 403 & 24 & 2.4 & 76 & 8.4 & 6.8 & 2.4 & 1.0 & 7.5 & \multirow{4}{*}{20} \\
\hline $\mathrm{RD}$ & 394 & 25 & 2.9 & 75 & 8.2 & 6.7 & 2.6 & 1.7 & 8.3 & \\
\hline PMU & 385 & 16 & 3.2 & 68 & 8.4 & 6.6 & 2.5 & 1.8 & 6.1 & \\
\hline PMD & 361 & 25 & 2.4 & 63 & 8.5 & 6.3 & 2.0 & 1.1 & 6.8 & \\
\hline
\end{tabular}

TN = Total Nitrogen; TP = Total Phosphorus; Transp. = Transparency; EC = Electric Conductivity DO = Dissolved Oxygen; Turb. $=$ Turbidity; TSS $=$ Total Suspended Solids; TOC $=$ Total Organic Carbon and RT $=$ water Retention Time. See Table 1 for sampling stations abbreviations 
cluster analysis (r-Pearson similarity) (PC-ORD - McCune and Meffort, 1995).

Correlation analyses (Pearson product-moment) were performed in order to identify the main factors influencing the phytoplankton biomass/numerical abundance - phosphorus, transparency, water retention time (RT) (data from Nogueira et al., 2006) and zooplankton abundance (data from Nogueira et al., 2008). The same analyses were used for detection of spatial patterns in diversity (reservoirs compartments, river longitudinal gradient and tributaries).

\section{Results}

Two hundred and thirty four taxa, distributed in 92 genera, were recorded in the phytoplankton assemblages of the Paranapanema River reservoirs and tributaries. Chlorophyta was the most specious group (98 taxa), followed by Bacillariophyta (58 taxa), Cyanophyta (32 taxa), Zygnemaphyta (21 taxa), Euglenophyta (8 taxa), Chrysophyta (7 taxa), Dinophyta (6 taxa), Cryptophyta (2 taxa) and Rodophyta (1 taxa).

Significant higher phytoplankton richness was observed in the fluvial stretches (tributaries and main river) when compared with the reservoirs $(\mathrm{p}<0.005)$ (Figure 2$)$. The Pardo River was an exception for this tendency, with the lowest number of taxa per sample among all stations (mean value of 30.4). The first sampling station (JU, before the influence of the first reservoir) and the ones corresponding to the Paranapanema mouth zone (upstream and downstream) into the Paraná River, exhibited the highest phytoplankton richness (mean values between 51 and 54) (Figure 2). When the reservoirs' longitudinal axis (intra-reservoir variation) was considered, a significant decreasing tendency in richness, from upstream to the dam zone, was observed $(\mathrm{p}=0.002)$ (Figure 2).

Seasonally, significant higher richness was observed during spring and lower in winter $(\mathrm{p}=0.004)$.

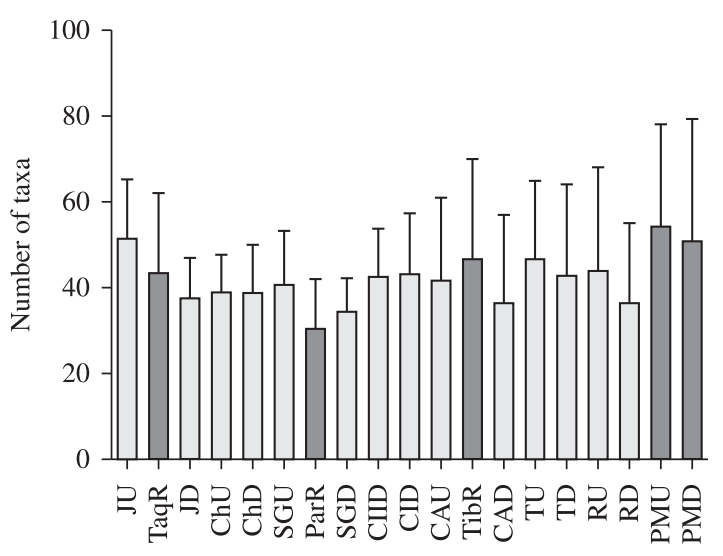

Figure 2. Phytoplankton richness (mean values and standard deviation) along the Paranapanema River reservoir cascade (reservoirs in grey; tributaries in dark grey). See Table 1 for abbreviations.
No significant differences in abundance either between tributaries and reservoirs $(p=0.29)$ or between different reservoir compartments (upstream and dam) $(p=0.20)$ were observed (Figure 3). Higher values of total phytoplankton abundance clearly occurred in the middle basin reservoirs (Canoas II, Canoas I and Capivara) and the lowest abundance was observed in the third studied reservoir (Salto Grande) along the cascade (Figure 3). Seasonally, the abundance was significantly lower in spring and higher in summer $(\mathrm{p}=0.003)$.

The phytoplankton abundance was positively correlated with the zooplankton abundance, as seen in Figure 4 $(\mathrm{r}=0.5887)$.

The chlorophyll- $a$ concentration was significantly higher $(\mathrm{p}=0.003)$ in the tributaries when compared to the reservoirs (Figure 5). Considering the intra-reservoir variability a significant decreasing tendency from upstream to the dam $(\mathrm{p}=0.001)$ was observed. Chlorophyll- $a$ concentrations were higher in summer for both studied years. Longitudinally, chlorophyll values were higher in the middle basin reservoirs. There was a positive linear correlation $(r=0.4213)$ between chlorophyll and phytoplankton numerical abundance (Figure 6), as expected.

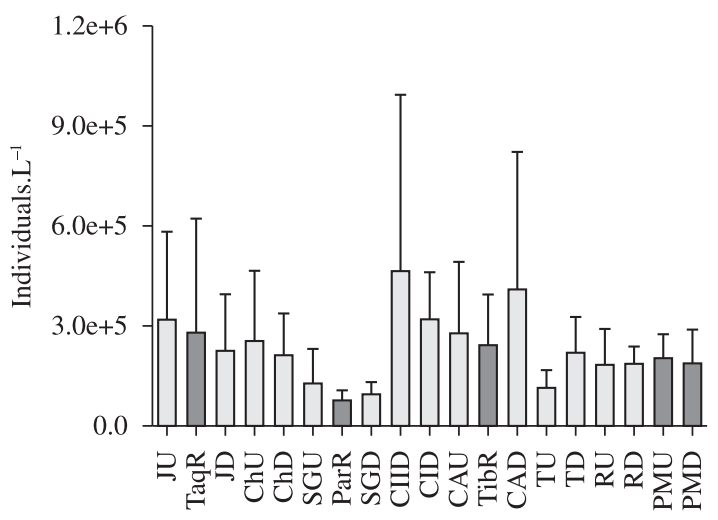

Figure 3. Phytoplankton abundance (mean values and standard deviation) along the Paranapanema River reservoir cascade (reservoirs in grey; tributaries in dark grey). See Table 1 for abbreviations.

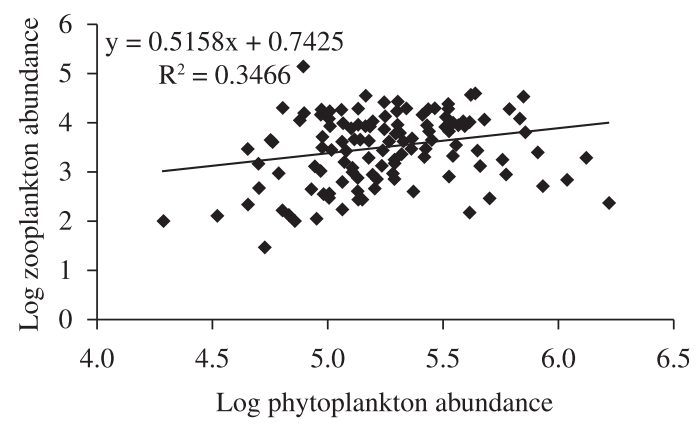

Figure 4. Linear correlation between phytoplankton and zooplankton abundances in the Paranapanema River reservoir cascade. 
The phytoplankton abundance was positively correlated with total dissolved phosphate $(r=0.1946)$ (Figure 7). The phytoplankton biomass (chlorophyll-a) was negatively correlated with transparency $(\mathrm{r}=0.496)$ (Figure 8) and water retention time $(\mathrm{r}=0.350)$ (Figure 9).

The relative abundance among the main phytoplankton groups is showed in Figure 10. The green algae, despite having a larger number of species, were not numerically dominant. Cryptophyceae was the most abundant group (49.4\%), followed by Bacillariophyceae (29.2\%). Cryptophyceae exhibited higher dominance during autumn and winter of the two consecutive years as well as in summer and spring of 2001 for most sampling stations. A conspicuous presence of Bacillariophyta occurred during summer of 2000 and, for the superior region of the cascade system, in the winter of 2000 and summer and spring of 2001. Chlorophyta had a relatively higher contribution only in the spring of 2000. In this sampling period, the abundance distribution among the different phytoplankton groups was more homogeneous in almost the entire system. Cyanophyta had lower density during summer and autumn of 2000 and a considerable increase in the spring of 2000 and summer of 2001. The highest percentage of this group occurred in the Capivara Reservoir.

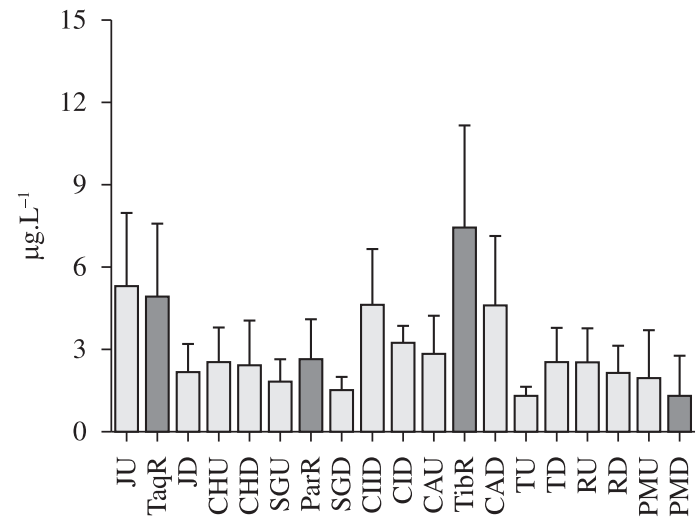

Figure 5. Phytoplankton biomass (chlorophyll-a) (mean values and standard deviation) along the Paranapanema River reservoir cascade (reservoirs in grey; tributaries in dark grey). See Table 1 for abbreviations.

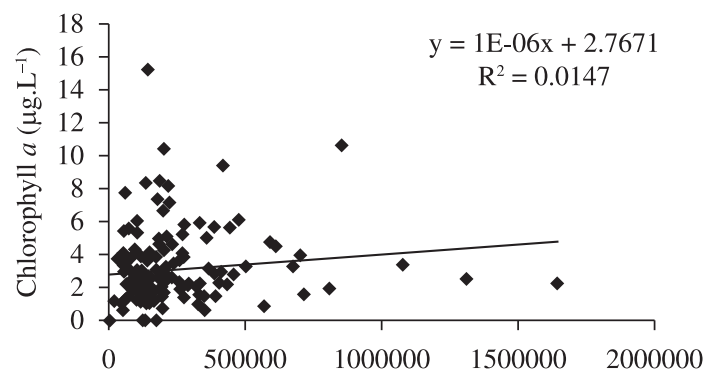

Phytoplankton abundance (individuals. $\mathrm{L}^{-1}$ )

Figure 6. Linear correlation between chlorophyll- $a$ and phytoplankton abundance in the Paranapanema River reservoir cascade.
Cryptomonas brasiliensis Castro, Bicudo and Bicudo can be considered as the main species of the phytoplankton in the studied reservoirs cascade. The specie was observed in all samples and its abundance ranged from $0.07 \%$, in Jurumirim Reservoir (dam zone) (July of 2000), to $94.8 \%$, in Capivara (upstream zone) (January of 2001). Among diatoms Discotella stelligera (Cleve and Grunow) Houk and Klee predominated in Chavantes Reservoir (dam zone), reaching $75.2 \%$ in January of 2001, and Asterionella formosa Hass in Pardo River, with a maximum of $64.5 \%$ in July of 2000. In relation to the green algae, the high

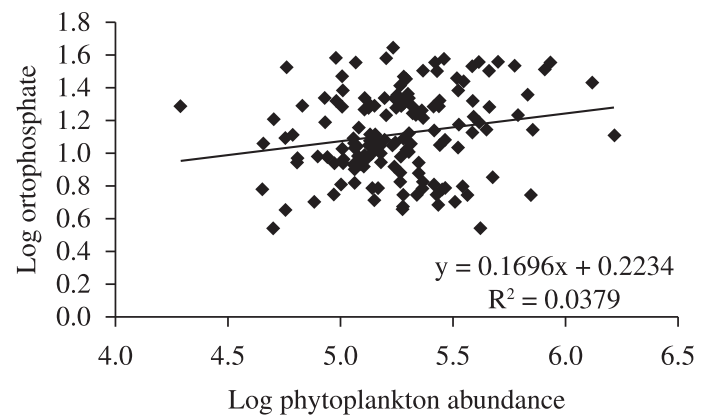

Figure 7. Linear correlation between phytoplankton abundance and ortophosphate in the Paranapanema River reservoir cascade.

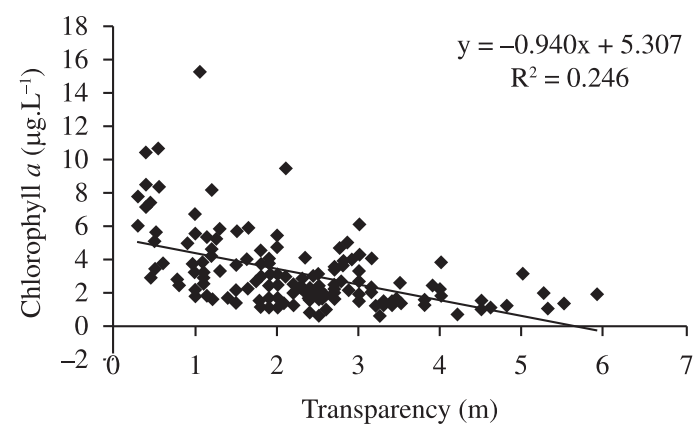

Figure 8. Linear correlation between chlorophyll- $a$ and transparency in the Paranapanema River reservoir cascade.

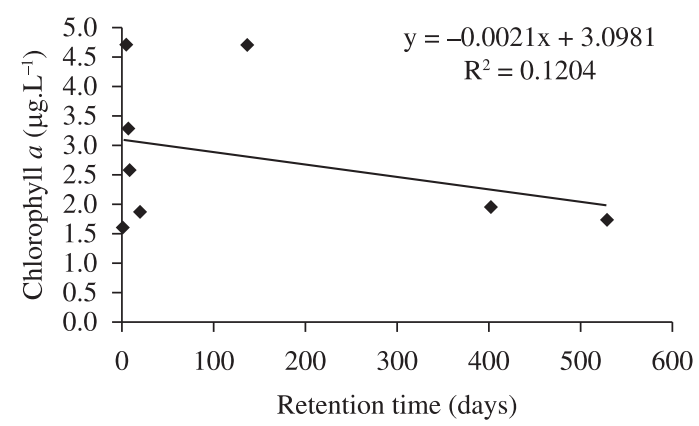

Figure 9. Linear correlation between chlorophyll- $a$ and water retention time in the Paranapanema River reservoir cascade. 
January/2000

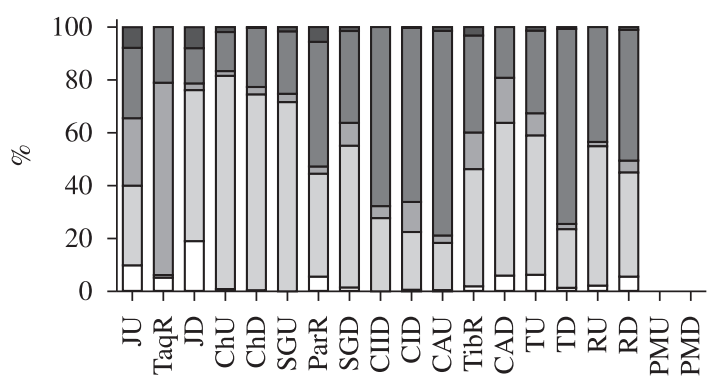

July/2000

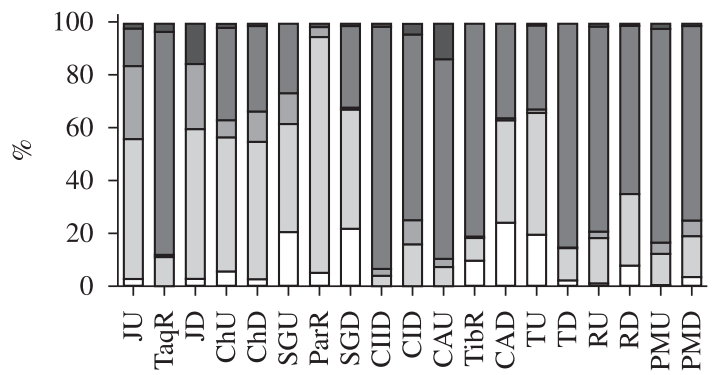

January/2001

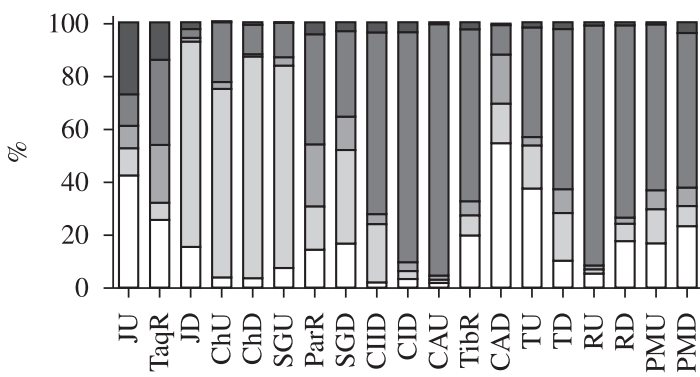

July/2001

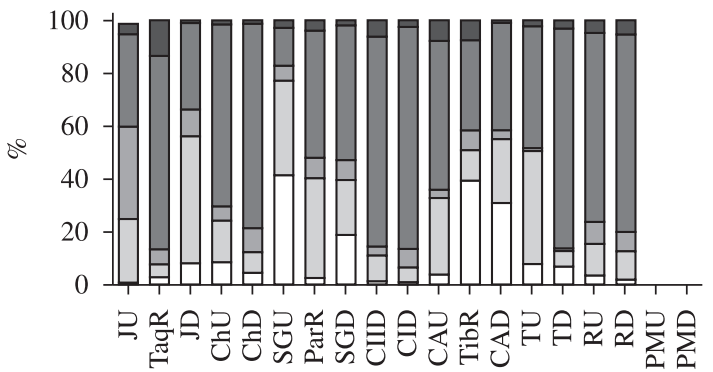

April/2000

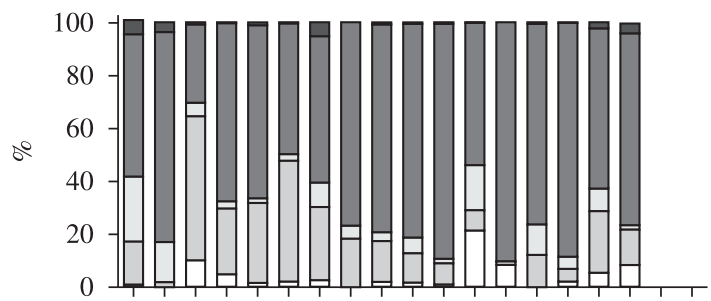

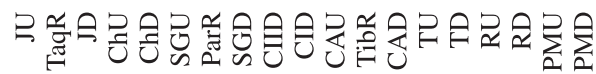

October $/ 2000$

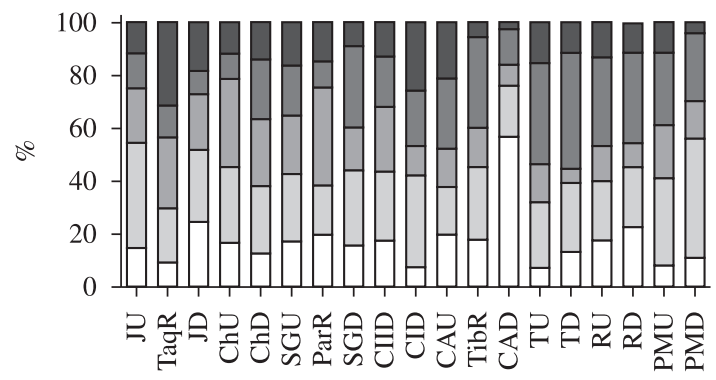

April/2001

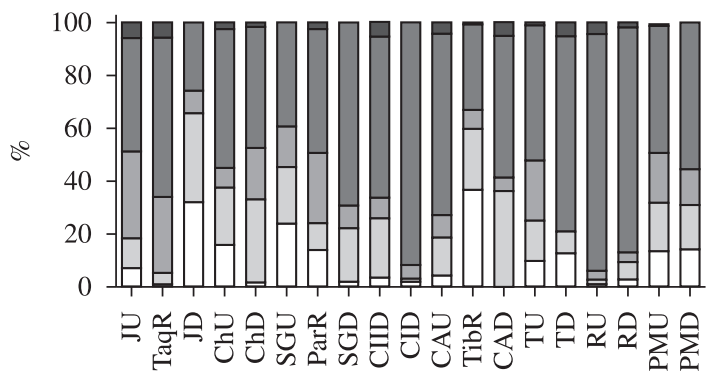

October/2001

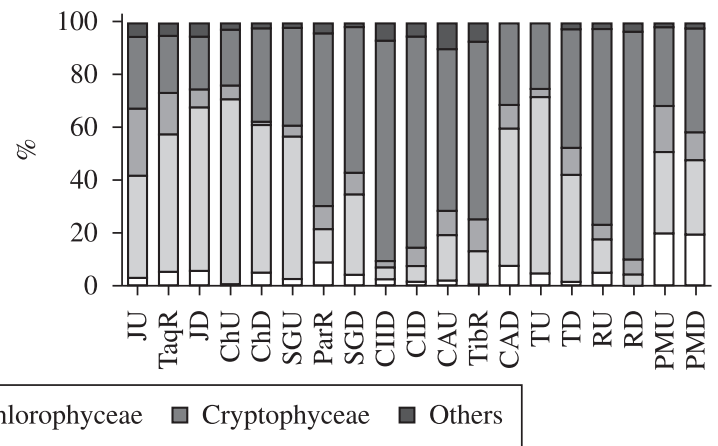

Figure 10. Relative abundance among the phytoplankton groups along the Paranapanema River reservoir cascade during the distinct sampling periods. See Table 1 for abbreviations.

contributions of Monoraphidium cf. contortum (Thur. ex Bréb.) Kom.-Legner in Jurumirim (upstream zone) (19.2\% in July of 2001); Chlorella spp. in Tibagi River (14.6\% in October of 2001) can be mentioned. Lepocinclis acus (O.F. Mül.) B. Marin and Melkonian in Taquari River (5.7\% in the July of 2000), and Phacus longicauda (Ehr.) Duj., in Canoas II Reservoir (4.2\% in July of 2001), were the main Euglenales. Among the blue-green algae, high contributions of Anabaena circinalis Rabenhorst ex Bornete and Flahault in Capivara Reservoir $27.1 \%$ in October of 2000) and Microcystis aeruginosa var. aeruginosa (Kutzing) Lemmermannin Tibagi River (9.8\% in October of 2000) were found.

Other important genera due to either high abundance peaks or wide distribution (spatial and temporal) were Chroomonas, among Cryptophyta; Stephanodiscus, 
Discotella, Aulacoseira, Nitzchia, Fragilaria, Navicula, Cymbella among Bacillariophyceae; Scenedesmus, Schroederia, Chlamydomonas, Dictyosphaerium, Botryococcus, Kirchneriella, Staurastrum and Actinastrum among Chlorophyta; Raphidiopsis, Synechocystis, Synechococcus, Pseudanabaena, Cylindropermopsis, Anabaena, Planktolyngbya, Planktothrix, among Cyanophyta; Peridinium and Gymnodinium among Pyrrhophyta and Dinobryon and Mallomonas among Chrysophyceae.

Higher values of phytoplankton diversity were observed at Jurumirim upstream, before the beginning of the cascade (Figure 11). A negative tendency in diversity along the cascade was verified $(r=0.86)$. Considering only the tributary rivers, a positive tendency towards the Paranapanema mouth was found $(r=0.80)$.

Phytoplankton diversity was significantly higher in the tributaries when compared with the reservoirs $(p=0.005)$. Intra-reservoir (upstream - dam zones) variation in diversity was not significant $(\mathrm{p}=0.21)$.

The lowest diversity (0.6) was observed in Canoas II Reservoir (July 2000) due to an almost complete dominance (92\% of total phytoplankton) of Cryptomonas sp. Canoas II and I Reservoirs generally had low values of diversity (Figure 11).

The assemblages diversity was significantly higher in spring ( $\mathrm{p}<0.005$ ), specially in October 2000 when most values were higher than 3.5 bits.ind $^{-1}$. In this period the highest diversity ( 4.5 bits.ind $^{-1}$ ) was calculated for Jurumirim Reservoir (dam zone) with Bacillariophyta, Chlorophyta and Cyanophyta exhibiting almost the same proportion (21\%). Cryptophyta, Euglenophyta and Dinophyta also had a similar contribution (8\%). The main species were Lyngbya putealis Montagne ex Gomont (15\%) and $D$. stelligera $(8 \%)$. Lower diversity values were found during summer.

The phytoplankton diversity was positively associated with the zooplankton diversity along the cascade (Figure 12).

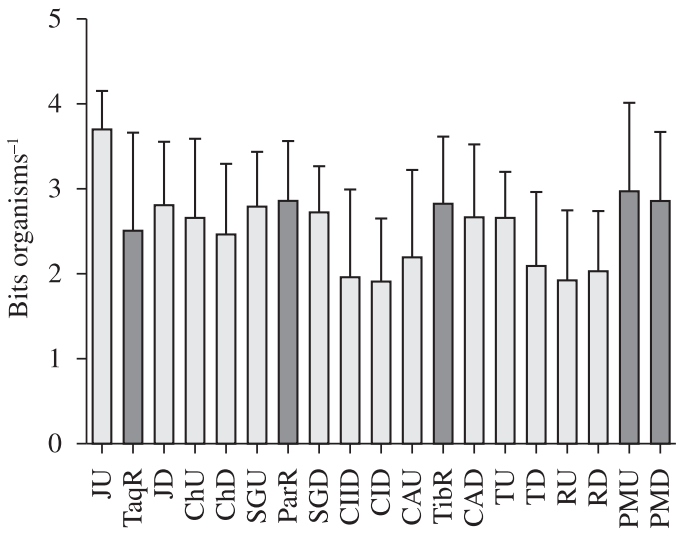

Figure 11. Diversity of phytoplankton assemblages (mean values and standard deviation) along the Paranapanema River reservoir cascade (reservoirs in grey; tributaries in dark grey). See Table 1 for stations abbreviations.
The cluster analysis (Figure 13), on the basis of the phytoplankton assemblage structure of each sampling station, showed that the better correlated sampling groups included reservoirs with low water retention times (Canoas I and II, Taquaruçu and Rosana Reservoirs). Other consistent groups included Chavantes Reservoir (upstream and dam) as well as the next river stretch (Salto Grande upstream). Similarity analyses evidenced that the most distinctive environments were the Tibagi River (the largest tributary of Paranapanema Basin) and the Jurumirim Reservoir (first in the cascade).

\section{Discussion}

Large Brazilian rivers have been intensively modified by construction of dams specially designed to integrate a complex hydroelectric production system. Such major physical transformation affects the entire river ecosystem structure and functioning (Tundisi et al., 1999; Barbosa et al., 1999; Jorcin and Nogueira, 2005a, b).

Several studies carried out in large Brazilian reservoirs have shown that the main factors influencing phytoplankton composition, density and biomass are water retention time, advection processes, vertical mixture regime, longitudinal and lateral gradients in physical and chemical conditions, as well as the indirect effects of important meteorological factors such as rainfall and wind (Santos and Calijuri, 1998; Nogueira, 2000; Gomes and Miranda, 2001; Calijuri et al., 2002; Matsumura-Tundisi and Tundisi, 2005). Nevertheless, despite the existence of several reservoir cascades in important rivers of the country, little information about the phytoplankton in these systems is available (Padisák et al., 2000; Silva et al., 2005). Integrated analyses with emphasis on phytoplankton in reservoir cascades are also rare for the rest of South America (Bonilla, 1997) and other continents (Mineeva et al., 2008).

The phytoplankton richness registered in the present study (234 taxa/92 genera) is high, compared to other studies on phytoplankton assemblages carried out in distinct Paranapanema basin aquatic environments with a similar number of analysed samples (Nogueira, 2000; BittencourtOliveira, 2002; Henry et al., 2006b; Ferrareze and Nogueira, 2006; Bicudo et al., 2006). Probably, this can be attributed

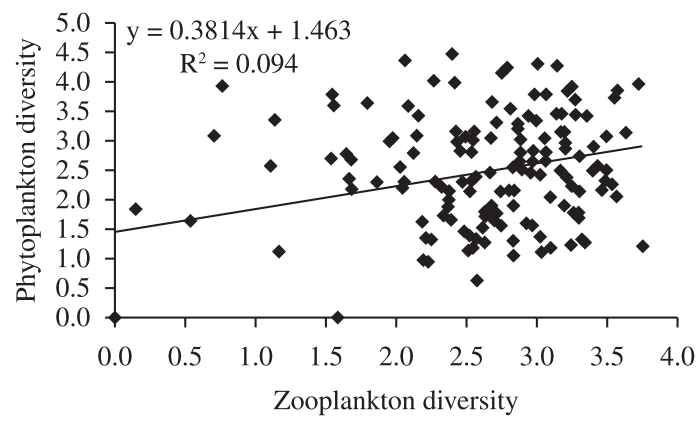

Figure 12. Linear correlation between zooplankton and phytoplankton diversities in the Paranapanema River reservoir cascade. 


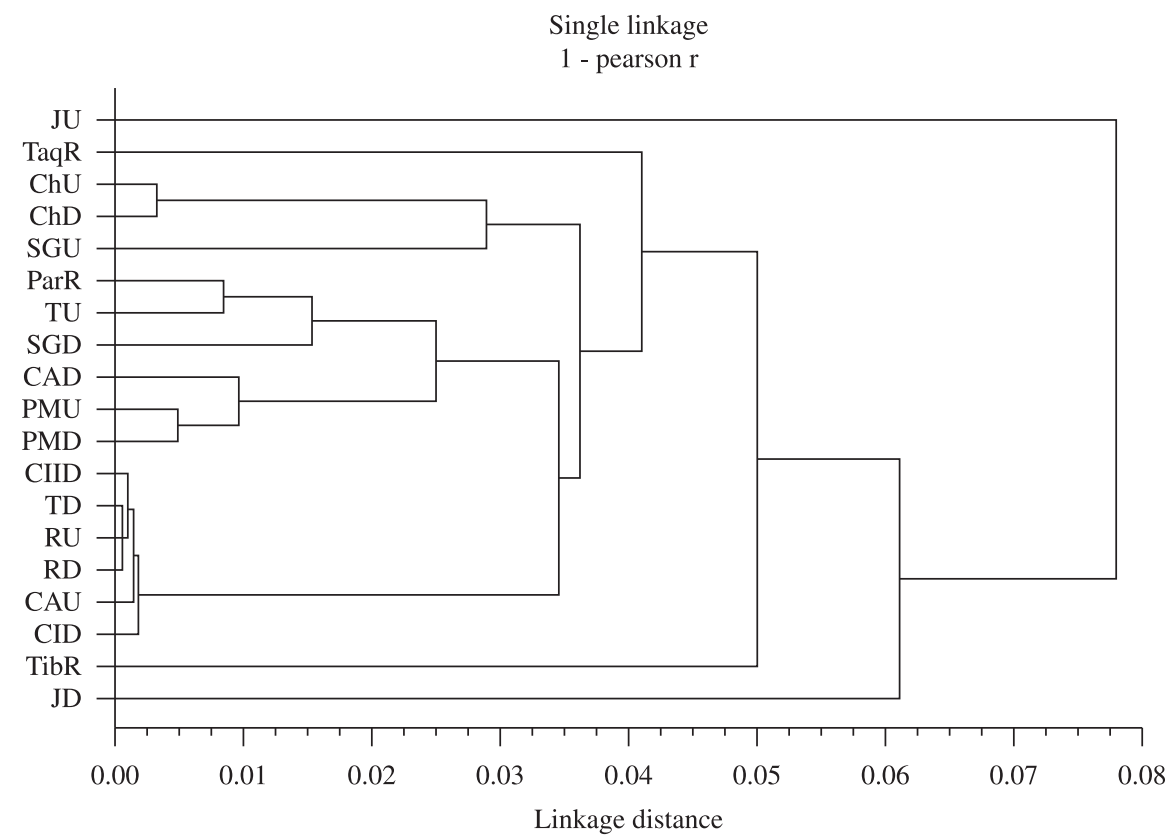

Figure 13. Similarity analysis among the sampling stations in the Paranapanema River reservoir cascade based on the abundance of the phytoplankton classes. See Table 1 for abbreviations.

to the extensive, spatially, sampling programme in which the present data originates. The same fact was verified for the zooplankton (Nogueira et al., 2008) and benthic macroinvertebrates (Jorcin and Nogueira, 2009), which were simultaneously sampled in the reservoir cascade. These results demonstrate the importance of considering larger spatial scales, if possible the whole hydrograph basin, in order to assess the biodiversity status of inland water ecosystems.

Despite an increasing tendency in richness along the cascade (inter-reservoir variation), towards the mouth, this pattern was not statistically corroborated.

The Chlorophyceae was the most specious phytoplankton group, followed by Bacillaryophyceae. This structural characteristic seems to be a consistent pattern for the phytoplankton assemblages in the basin. High richness of Chlorophyceae and Bacillaryophyceae has also been observed by Nogueira (2000) for Jurumirim Reservoir, the first in the cascade; by Bittencourt-Oliveira (2002) for the largest Paranapanema tributary, the Tibagi River; by Henry et al. (2006b) for three lateral lakes to the Paranapanema River just before the Jurumirim Reservoir upstream stretch; by Ferrareze and Nogueira (2006) for lotic stretches of the Paranapanema River and tributaries and by Bicudo et al. (2006) for Rosana, the last reservoir in the series. The dominance, in richness, of Chlorophyceae and Bacillaryophyceae was also reported for other large rivers and reservoirs in La Plata basin (Bonilla, 1997; Padisák, 2000; De Léon and Chalar, 2003; Silva et al., 2005).

The Paranapanema River dams seem to have a negative effect on phytoplankton richness, as higher number of taxa was associated to riverine conditions. A similar pattern was observed for the benthic macroinvertebrates, which decreased in richness and abundance in the deeper and higher retention time reservoirs of the cascade (Jorcin and Nogueira, 2008). Bicudo et al. (2006), following the filling up process of Rosana Reservoir, observed a diminution in the diversity values of the phytoplankton assemblages.

The first sampling station (upstream of Jurumirim), before the influence of the first dam, as well as the tributaries (except Pardo River) exhibited higher phytoplankton richness and diversity. Matsumura-Tundisi and Tundisi (2005) studying the spatial structure of the eutrophic Reservoir of Barra Bonita in the adjacent basin (towards north) of the Tietê River (São Paulo, Brazil), also observed the highest phytoplankton richness in an important tributary (Piracicaba River). Thus, it is imperative to consider the lateral dimension, in addition to the longitudinal one, for aquatic biota inventories in large basins/reservoirs. The same consideration is stressed by Mineeva et al. (2008) based on the effect of the Oka River entrance in the Volga reservoirs cascade (Russia) on the phytoplankton biomass. In the case of the Paranapanema cascade, typical water quality parameters (nutrients, transparency, turbidity, etc.) indicate that higher degradation is mainly associated to the tributaries (Jorcin and Nogueira 2005a, b). The Pardo River, for instance, receives a large amount of domestic sewage from several municipalities along its course, and the Tibagi River is highly influenced by intensive agriculture practices.

The dam construction along large rivers probably causes a strong organizational disruption in the natural longitudinal pattern. The expected addition of species towards the river mouth (Vannote et al., 1980) was just a weak tendency 
for the phytoplankton in the Paranapanema basin. Jorcin and Nogueira (2008), for benthic macroinvertebrates, and Nogueira et al. (2008), for zooplankton, did not observe a longitudinal increment in richness too. Nevertheless, a progressive increase in species number does occur for the fish fauna (Britto and Carvalho, 2006).

Age and morphological complexity of each reservoir in the cascade are also important factors interfering in the phytoplankton richness and diversity. Canoas I and Canoas II, the newest reservoirs in the Paranapanema cascade, were the ones with lower phytoplankton diversity. The Jurumirim spatial complexity effect on the phytoplankton productivity and structure has been already well demonstrated (Henry et al., 1998; Nogueira, 2000). Another particularity that influences richness and diversity is the connectivity with lateral wetlands, mainly with seasonal or permanent lakes containing a huge amount of different microhabitats (macrophyte-dominated). This is certainly related to the influence of the periphyton assemblages. This positive effect in diversity has also been reported for the microcrustaceans assemblages (Nogueira et al., 2008) and is certainly responsible for the consistently high values exhibited by the phytoplankton in the first sampling station (Upstream Jurumirim). Such areas along the cascade must be considered as strategic sites for conservation policy in the basin.

Phytoplankton and zooplankton (Nogueira et al., 2008) diversity were positively associated along the cascade.

A clear increase of phytoplankton abundance was observed in the middle stretch of the reservoir cascade (Canoas II, Canoas I and Capivara Reservoirs). The same pattern was observed for the periphytic community by Felisberto and Rodrigues (2005). Higher abundance of phytoplankton in the middle Paranapanema basin is explained by the increase of the trophic conditions in this stretch (Jorcin and Nogueira 2005a, b), as demonstrated by the positive correlation between phosphorus concentration in the water and chlorophyll data. Henry (1990) had already demonstrated, experimentally, that phosphate enrichment stimulates the phytoplankton growth in Jurumirim Reservoir.

According to Gomes and Miranda (2001), an important factor responsible for the recurrent low values of chlorophyll in the upper Paraná basin reservoirs is the predominant high flow, besides the scarcity of some important mineral nutrients other than $\mathrm{N}$ and $\mathrm{P}$, minor essential ions such as carbon, potassium, calcium, magnesium and iron. In the Paranapanema cascade, the phytoplankton development in Taquaruçu, and especially in Salto Grande Reservoir, where the nutrient concentration is higher, is negatively influenced by the fast water flow (RT) (ca. 8 and 1.5 days, respectively). Phytoplankton control by advection processes (wash-out) is an efficient strategy to reduce the eutrophication effects, mainly the Cyanophyceae growth (Kimmel et al., 1990; Steinberg and Gruhl, 1992; Reynolds et al., 1994; Padisák et al., 1999). Felisberto and Rodrigues (2005) found a low periphytic biomass in Salto Grande Reservoir and attributed that fact to the high water flow too. The same argument was used by Bonilla (1997) to explain a decrease in phytoplankton density in the intermediate of three reservoirs of the Río Negro cascade in Uruguay. However, this pattern can not be considered an exclusive rule, as the chlorophyll concentrations in the reservoirs of the cascade with higher water retention (Jurumirim and Chavantes) (between 400 and 630 days) did not exceeded $3 \mu \mathrm{g} . \mathrm{L}^{-1}$ (mean values). In fact, there was a negative correlation between phytoplankton biomass and the reservoirs water retention time.

Among the large rivers of the high Paraná basin, the Paranapanema has been considered as a system that preserves a relatively good "water quality" condition, with several reservoirs classified as oligotrophic (Henry, 1993; Jorcin and Nogueira 2005a, b; Nogueira et al., 2008). In the present study the maximum concentration of chlorophyll was $8 \mu \mathrm{g} . \mathrm{L}^{-1}$ (mean value) while in the adjacent Tietê Reservoir cascade the values in the upstream reservoirs can reach more than $50 \mu \mathrm{g} . \mathrm{L}^{-1}$ (Tundisi et al., 1991; Padisák et al., 2000) or even more than $400 \mu \mathrm{g} . \mathrm{L}^{-1}$ during phytoplankton blooms (Calijuri et al., 2002). Phytoplankton biomass was slightly higher in the last two sampling stations (Paranapanema mouth upstream and downstream), in the Paraná River, compared to the sampling points in the Paranapanema lower stretch. A dilution effect due to the input of more oligotrophic water could even be considered, as the chlorophyll in the Paraná River was lower after the Paranapanema mouth.

The negative correlation between water transparency and chlorophyll shows that the light conditions in the Paranapanema basin seems not to be a limiting factor for phytoplankton development. This result was influenced by higher abundances in stretches/reservoirs where riverine conditions predominate, with phytoplankton assemblages dominated by species tolerant to turbulent conditions and typical high mineral turbudity (e.g. Cryptopheceae - functional group Y, C-strategist, sensu Reynolds et al., 2002).

Different from natural lakes, phytoplankton dynamics in rivers is dominated by physical interactions, and those biotic interactions are traditionally believed to regulate limnetic communities being suppressed and rarely wellexpressed (Reynolds et al., 1994). This seems to apply to the Paranapanema reservoir cascade, where the zooplankton (microcrustaceans) probably does not have a significant control on the phytoplankton abundance. A positive correlation between phytoplankton and zooplankton (microcrustaceans) (Nogueira et al., 2008) along the Paranapanema cascade was observed. Evidence on the inability of zooplankton to shape and control the phytoplankton in the tropics are provided by Melo and Huszar (2000) and Rückert and Giani (2008). Nevertheless, further investigation is still necessary to corroborate this hypothesis as reservoirs cascades are complex systems and, as pointed out by Mineeva et al. (2008), phytoplankton maybe controlled by physical processes in the run-of-the-river reservoirs (fast flow) while the biotic interactions would be more important in high water retention time systems (accumulation reservoirs).

Phytoplankton composition and structure, even in major taxonomical categories, showed to be a good indicator 
of the different systems of operation of reservoirs in the Paranapanema cascade and also reflected the changes in trophic conditions.

In the summer (January) campaign of 2001, for instance, a conspicuous substitution of the dominant groups along the cascade was observed. Before the zone of the influence of the first dam (Upstream of Jurumirim), where fluvial conditions and high productivity predominate (Henry et al., 1998; Nogueira, 2000), all the main algae groups were well represented. In the stratified lacustrine environments of Jurumirim and Chavantes Reservoirs, the assemblages were dominated by small unicellular diatoms, mainly D. stelligera. In the middle Paranapanema region, where the reservoirs have a low water retention time, there was a high abundance of Cryptophyceae. In the next reservoir, Capivara, the most eutrophic in the series and with relatively high water retention time (130 150 days), Cyanophyceae were dominant. Finally, in the low Paranapanema stretch, Cryptophyceae dominated again.

In general, the phytoplankton was numerically dominated by Bacillariophyceae and Cryptophyceae. The same pattern is described by Ferrareze and Nogueira (2006) for the main tributary rivers and non-reservoir stretches of the Paranapanema basin.

Only in the spring (October) campaign of 2000, there was a higher proportionality among the main phytoplankton groups along the cascade.

Chlorophyceae, despite their large number of species, exhibited a minor quantitative contribution. Diatoms were particularly prominent in the large upstream reservoirs (Jurumirim and Chavantes) and the Cryptophyceae exhibited a total dominance in the river-passage (low retention time) reservoirs in the middle of the basin. Significant peaks of Cryptophyceae were also described for the cascade of reservoirs in the Iguaçu River, in the southern State of Paraná (Silva et al., 2005). The hypothesis of an alternative heterotrophic strategy of Cryptophyceae (Hammer et al., 2002) was not verified, since there was no correlation with dissolved organic carbon concentration.

Cyanophyceae reached more than $50 \%$ of the phytoplankton numerical abundance only in the lacustrine zone of Capivara (Spring 2000 and Summer 2001). The relative low abundance of this group can be attributed to the predominant oligotrophic conditions of the larger two first reservoirs and to the prevalent low retention time (non-equilibrium state) (Becker et al., 2008) of the others, except for Capivara, in the cascade.

Silva et al. (2005) concluded that there is no significant cascading effect on phytoplankton in the reservoirs of the Iguaçu River. The hydrodynamics was the main factor affecting the assemblage structure of each reservoir. Bonilla (1997) also found a similar phytoplankton composition among the three reservoirs of the Negro River (Uruguay) due to the intensive flow. In the case of the Paranapanema cascade, the cluster analysis showed that the low retention time is an important factor (group formed by Canoas I, Canoas II, Taquaruçu and Rosana Reservoirs), but it is not exclusive in the determination of the phytoplankton structure. A high retention time reservoir (Chavantes) can also determine the phytoplankton composition and abundance of the next reservoir (Salto Grande upstream).

Reservoirs generally have the capability to retain nutrients, from point and non-point sources, and this fact supports the idea that a progressive "oligotrophication" process should be expected along reservoir cascades (Tundisi et al., 1991; Armengol et al., 1999). This hypothesis seems to apply well to river basins heavily polluted in their upstream zones (e.g. Tietê River - Brazil; Ter River - Spain). Nevertheless, our data, as well as the ones of Silva et al. (2005), Felisberto and Rodrigues (2005), Meiling et al. (2007) and Mineeva et al. (2008), do no adjust to the above mentioned model, as an increase in the trophic conditions (and phytoplankton abundance) was clearly seen in the middle cascade region. There was also no adjustment to the Cascading Reservoir Continuum Concept (Barbosa et al., 1999), as an exclusive (predictable/progressive) gradient, downstream of the first large reservoir of the series, was not detected.

Acknowledgements - The authors are grateful to Fapesp (Fundação de Amparo à Pesquisa do Estado de São Paulo) (process 99/09667-9) and CNPq (Conselho Nacional de Desenvolvimento Científico e Tecnológico) for financial support. We also deeply appreciate the contribution of Marcelo Mendes for laboratory assistance, and that of the Duke Energy technicians, particularly Norberto Castro Vianna and Yvana C. T. Britto, for contributions during the field work and of R. Henry and Glen George for the constructive comments during the manuscript preparation.

\section{References}

AGOSTINHO, AA., GOMES, LC. and PELICICE, FM., 2007. Ecologia e manejo de recursos pesqueiros em reservatórios do Brasil. Maringá: EDUEM. 501 p.

ARMENGOL, J., GARCIA, JC., COMERMA, M., ROMERO, M., DOLZS, J., ROURA, M., HAN, BH., VIDAL, A. and ŠIMEK, K., 1999. Longitudinal Processes in Canyon Type Reservoirs: the case of Sau (N.E. Spain). In TUNDISI, JG. and STRASKRABA, M. (Eds.). Theoretical Reservoir Ecology and its Applications. Leiden: Brazilian Academy of Sciences, International Institute of Ecology and Backhuys Publishers. p. 313-345.

BARBOSA, FAR., PADISAK, J., ESPINDOLA, ELG., BORICS, G. and ROCHA, O., 1999. The cascading reservoir continuum concept (CRCC) and its application to the river Tietê-Basin, São Paulo State, Brazil. In TUNDISI, JG. And STRASKRABA, M. (Eds.). Theoretical Reservoir Ecology and its Applications. Leiden: Brazilian Academy of Sciences, International Institute of Ecology and Backhuys Publishers. p. 425-437.

BECKER, V., HUSZAR, VLM., NASELLI-FLORES, L. and PADISÁK, J., 2008. Phytoplankton equilibrium phases during thermal stratification in a deep subtropical reservoir. Freshwater Biology, vol. 53 p. 952-963.

BICUDO, DC., FERRAGUT, C., CROSSETTI, LO. and BICUDO, CEM., 2006. Efeitos do represamento sobre a estrutura da comunidade fitoplanctônica do Reservatório de Rosana, baixo rio Paranapanema, Estado de São Paulo. In NOGUEIRA, MG., HENRY, R. and JORCIN, A. (Eds.). Ecologia de reservatórios: 
impactos potenciais, ações de manejo e sistemas em cascata. São Carlos: RiMa Editora. p. 349-377.

BITTENCOURT-OLIVEIRA, MC., 2002. A comunidade fitoplanctônica do Rio Tibagi: uma abordagem preliminar de sua diversidade. In MEDRI, ME., BIANCHINI, E., SHIBATTA, OA. and PIMENTA, JÁ. (Eds.). A bacia do rio Tibagi. Londrina: Universidade Estadual de Londrina. p. 373-402.

BONILLA, S., 1997. Composición y abundancia fitoplanctónicas de tres embalses en cadena sobre el río Negro, Uruguay. Iheringia, Série Botânica, vol. 49, p. 47-61.

BRITTO, SGC. and CARVALHO, ED., 2006. Ecological attributes of fish fauna in the Taquaruçu reservoir, Paranapanema River (upper Paraná, Brazil): composition and spatial distribution. Acta Limnologica Brasiliensia, vol. 18, no. 4, p. 377-388.

CALIJURI, MC., SANTOS, ACA. and JATI, S., 2002. Temporal changes in the phytoplankton community structure in a tropical and eutrophic reservoir (Barra Bonita, SP-Brazil). Journal of Plankton Research, vol. 24, p. 617-634.

DE LEÓN, L. and CHALAR, G., 2003. Abundancia y diversidad del fitoplancton en el Embalse de Salto Grande (ArgentinaUruguay). Ciclo estacional y distribución espacial. Limnetica, vol. 22 , no. $1-2$, p. $103-113$.

FELISBERTO, SA. and RODRIGUES, L., 2005. Periphytic Community of a Reservoirs Cascade in the Paranapanema River, Brazil. Acta Scientiarum, vol. 27, no. 3, p. 215-223.

FERRAREZE, M. and NOGUEIRA, MG., 2006. Phytoplankton assemblages in lotic systems of the Paranapanema Basin (Southeast Brazil). Acta Limnologica Brasiliensia, vol. 18, no. 4 , p. 389-405.

GOLTERMAN, HL., CLYMO, RS. and OHSTAD, MA., 1978. Methods for physical and chemical analysis of fresh waters. 2. ed. Oxford: Blackweel Scientific Publications. 213 p.

GOMES, LC. and MIRANDA, LE., 2001. Hydrologic and climatic regimes limit phytoplankton biomass in reservoirs of the Upper Paraná River Basin, Brazil. Hydrobiologia, vol. 457, p. 205-214.

HAMMER, R., SCHUMANN, B. and SCHUBERT, H., 2002. Light and temperature acclimation of Rhodomonas salina (Cryptophyceae): photosynthetic performance. Aquatic Microbial Ecology, vol. 29, p. 287-296.

HENRY, R., 1990. Amônia ou fosfato como agente estimulador do crescimento do fitoplâncton da Represa de Jurumirim (Rio Paranapanema, SP). Revista Brasileira de Biologia $=$ Brazilian Journal of Biology, vol. 50, no. 4, p. 883-892.

-, 1993. Thermal regime and stability of Jurumirim Reservoir (Paranapanema River, São Paulo, Brazil). Internationale Revue der Gesamte Hydrobiologie, vol. 78, no. 4, p. 501-511.

HENRY, R., NOGUEIRA, MG., POMPÊO, MLM. and MOSCHINICARLOS, V., 2006a. Annual and short-term variability on primary productivity by phytoplankton and correlated abiotic factors in Jurumirim Reservoir (São Paulo, Brazil). Brazilian Journal of Biology, vol. 66, no. 1b, p. 239-261.

HENRY, R., NUNES, MA., MITSUKA, PM., LIMA, N. and CASANOVA, RSMC., 1998. Variação espacial e temporal da produtividade primária pelo fitoplâncton na Represa de Jurumirim (Rio Paranapanema, SP). Revista Brasileira de Biologia $=$ Brazilian Journal of Biology, vol. 58, no. 4, p. 571-590.
HENRY, R., USHINOHAMA, E., FERREIRA, RAR., 2006b. Fitoplâncton em três lagoas marginais ao Rio Paranapanema e em sua desembocadura no Reservatório de Jurumirim (São Paulo, Brasil) durante um período prolongado de seca. Revista Brasileira de Botânica, vol. 29, p. 399-414.

JORCIN, A. and NOGUEIRA, MG., 2005a. Phosphate distribution along a cascade of reservoirs (Paranapanema River, SE, Brazil). In SERRANO, L. and GOLTERMAN, HL. (Eds.). Phosphates in Sediments: proceedings of the $4^{\text {th }}$ International Symposium. Leiden: Backhuys Publishers. p. 77-86.

-, 2005b. Temporal and spatial patterns along the cascade of reservoirs in the Paranapanema River (SE Brazil) based on the characteristics of sediment and sediment-water interface. Lakes and Reservoirs Research and Management, vol. 10, no. 1, p. 1-12.

-, 2008. Benthic macroinvertebrates in the Paranapanema reservoir cascade (southeast Brazil). Brazilian Journal of Biology, vol. 68, no. 47 , p. $1013-1024$.

-, 2009. Spatial and temporal distribution of the zoobenthos community during the filling up period of Porto Primavera Reservoir (River Paraná, Brazil). Brazilian Journal of Biology, vol. 69 , no. 1, p. 631-637.

KENNEDY, RH., TUNDISI, JG., STRASKRABA, V., LIND, OT. and HEJZLAR, J., 2003. Reservoirs and the limnologist's growing role in sustainable water resource management. Hydrobiologia, vol. 504, p. 11-12.

KIMMEL, BL., LIND, OT. and PAULSON, LJ., 1990. Reservoir primary production. In THORNTON, KW., KIMMEL, BL. and PAYNE, FE. (Eds.). Reservoir Limnology: ecological perspectives. New York: John Wiley and Sons. p. 133-193.

KREBS, CJ., 1989. Ecological metodology. New York: Harper and Hall. 620 p.

MATSUMURA-TUNDISI, T. and TUNDISI, JG., 2005. Plankton richness in a eutrophic reservoir (Barra Bonita Reservoir, SP, Brazil). Hydrobiologia, vol. 542, p. 367-378.

McCUNE, B. and MEFFORD, MI., 1995. PC-ORD: multivariate analysis of ecological data. Version 2.0. Gleneden Beach: MjM Software Design.

MEILING, S., XINQIN, H., ZHICAI, X., XINGHUAN, J., RUIQIU, L. and QINGHUA, C., 2007. Comparative study on macroinvertebrate communities along a reservoir cascade in Xiangxi River Basin. Acta Ecologica Sinica, vol. 27, no. 12, p. 4963-4971.

MELO, S. and HUSZAR, VLM., 2000. Phytoplankton in Amazonian floodplain lake (Lago Batata, Brasil): diel variation and species strategies. Journal of Plankton Research, vol. 22, p. 63-76.

MINEEVA, NM., LITVINOV, AS., STEPANOVA, IE. and KOCHETKOVA, MYU., 2008. Chlorophyll content and factors affecting its spatial distribution in the Middle Volga reservoirs. Inland Water Biology, vol. 1, no. 1, p. 64-72.

NALIATO, DAO., NOGUEIRA, MG. and PERBICHE-NEVES, G., 2009. Discharge pulses of hydroelectric dams and their effects in the downstream limnological conditions: a case study in a large tropical river (SE, Brazil). Lakes and Reservoirs: Research and Management. vol. 14, p. 301-314.

NOGUEIRA, MG., 2000. Phytoplankton composition, dominance and abundance as indicators of enviromental compartmentalization in Jurumirim Reservoir (Paranapanema River), São Paulo, Brazil. Hydrobiologia, vol. 431, p. 115-128. 
NOGUEIRA, M. G.; JORCIN, A.; VIANNA, N. C. and BRITTO, Y. C. T., 2006. Reservatórios em cascata e os efeitos na limnologia e organização das comunidades bióticas (fitoplâncton, zooplâncton e zoobentos) - um estudo de caso no rio Paranapanema (SP/PR). In NOGUEIRA, M. G.; HENRY, R. and JORCIN, A. (orgs). Ecologia de reservatórios - impactos potenciais, ações de manejo e sistemas em cascata. São Carlos. Rima Editora. 83-125. (2da. Ed.).

NOGUEIRA, MG., OLIVEIRA, PCR. and BRITTO, YCT., 2008. Zooplankton Assemblages (Copepoda And Cladocera) in a cascade of reservoirs of a large tropical river (SE, Brazil). Limnetica, vol. 27, no. 1, p. 151-170.

PADISÁK, J., BARBOSA, FAR., BORBELY, G., BORICS, G., CHORUS, I., ESPÍNDOLA, ELG., HEINZE, R., ROCHA, O., TÖRÖKNÉ, AK. and VASAS, G., 2000. Phytoplankton composition, biodiversity and a pilot survey of toxic cyanoprokaryotes in a large cascading reservoir system (Tietê basin, Brazil). Verh Internatational Verein Limnology, vol. 27, p. 2734-2742.

PADISÁK, J., KÖHLER, J. and HOEG, S., 1999. The effect of changing flushing rates on development of late summer Aphanizomneon and Microcystis populations in a shallow lake, Müggelsee, Berlin, Germany. In TUNDISI, JG. and STRASKRABA, M. (Eds.). Theoretical Reservoir ecology and its applications. Leiden: Brazilian Academy of Sciences, International Institute of Ecology and Backhuys Publishers. p. 411-423.

REYNOLDS, CS., DESCY, JP. and PADISÁK, J., 1994. Are phytoplankton dynamics in rivers so different from those in shallow lakes? Hydrobiologia, vol. 289, p. 1-7.

REYNOLDS, CS., HUSZAR, VLM., KRUK, C., FLORES, LN. and MELO, S., 2002. Towards a functional classification of the freshwater phytoplankton. Journal of Plankton Research, vol. 24, p. 417-428.

RÜCKERT, GV. and GIANI, A., 2008. Biological interactions in the plankton community of a tropical eutrophic reservoir: is the phytoplankton controlled by zooplankton? Journal of Plankton Research, vol. 30, p. 1157-1168.

SANTOS, ACA. and CALIJURI, MC., 1998. Survival strategies of some species of the phytoplankton community in the Barra Bonita reservoir (São Paulo, Brazil). Hydrobiologia, vol. 367, p. $139-152$

SILVA, CA., TRAIN, S. and RODRIGUES, LC., 2005. Phytoplankton Assemblages in a Brazilian Subtropical cascading reservoir system. Hydrobiologia, vol. 537, p. 99-109.
SOARES, MCS., MARINHO, MM., HUSZAR, VLM., BRANCO, CWC. and AZEVEDO, SMFO., 2008. The effects of water retention time and watershed features on the limnology of two tropical reservoirs in Brazil. Lakes and Reservoirs: Research and Management, vol. 13, p. 257-269.

STATSOFT., 2006. Statistica (data analysis software system). Version 6. Tulsa. Software.

STEINBERG, CEW. and GRUHL, E., 1992. Physical measures to inhibit planktonic cyanobacteria. In SUTCLIFFE, DW. and JONES, JG. (Eds.). Eutrophication: Research and Application to Water Supply. Cumbria: Freshwater Biological Association. p. $163-184$

TALLING, JF. and DRIVER, D., 1963. Some problems in the estimation of chlorophyll a in phytoplankton. In Proceedings, Conference of primary productivity measurements in marine and freshwater. Hawaii: USAEE. p. 142-146.

TUNDISI, JG. and MATSUMURA-TUNDISI, T., 2003. Integration of research and management in optimizing multiple uses of reservoirs: the experience in South America and Brazilian case studies. Hydrobiologia, vol. 500, p. 231-242.

TUNDISI, JG., MATSUMURA-TUNDISI, T. and ROCHA, O., 1999. Theoretical basis for reservoir management. In TUNDISI, JG. and STRASKRABA, M. (Eds.). Theoretical reservoir ecology and its applications. Leiden: Brazilian Academy of Sciences, International Institute of Ecology and Backhuys Publishers. p. 505-528.

TUNDISI, JG., MATSUMURA-TUNDISI, T., CALIJURI, MC. and NOVO, EML de M., 1991. Comparative limnology of five reservoirs in the middle Tietê River, São Paulo State. Verh Internatational Verein Limnology, vol. 24, p. 1489-1496.

TUNDISI, JG., MATSUMURA-TUNDISI, T. and CALIJURI, MC., 1993. Limnology and management of reservoirs in Brazil. In STRASKRABA, M., TUNDISI, JG. and DUNCAN, AC. (Eds.). Comparative reservoir limnology and water quality management. Netherlands: Kluwer Academic Publishers. p. 25-55.

VANNOTE, RL., MINSHALL, GW., CUMMINS, KW., SEDELL, JR. and CUSHING, CE., 1980. The river continuum concept. Canadian Journal of fisheries and Aquatic Sciences, vol. 37, p. 130-137. 